\title{
Nomadic Research Practices in Early Childhood: Interrupting Racisms and Colonialisms
}

\author{
Veronica Pacini-Ketchabaw \\ University of Victoria, Canada \\ Fikile Nxumalo, \\ University of Victoria, Canada \\ Carol Rowan \\ University of Victoria, Canada \\ Corresponding Author: \\ Veronica Pacini-Ketchabaw \\ School of Child and Youth Care, University of Victoria \\ PO Box 1700 STN CSC, Victoria, British Columbia V8W 2Y2 \\ vpacinik@uvic.ca
}

\begin{abstract}
This paper considers how research practices on racialization in early childhood education might be reconceptualized when racialization is placed within relational intricacies and affects in multiple encounters. By foregrounding race and its emergence in multifarious, unpredictable ways in everyday encounters between human and non-human bodies, space, and discourse, the paper investigates how a movement toward research analyses that engage with both the materiality of race and its systemic and discursive formations might be used to constantly seek new ethical ways of responding to and acting against racisms and colonialism in early childhood.
\end{abstract}

\begin{abstract}
A biracial (African/Asian) child in a small early childhood classroom in North America draws herself as a blonde, blue-eyed Rapunzel, saying, "I have really long, long hair." The drawing activates and charges race-fears, stereotypes of desirable beauty, histories of racialization within a racialized regime of vision-for the educator and the researchers. So we ask, where else can this go? The educator decides to provide opportunities for all the children in the classroom to draw. Our interest was in exploring "other" possibilities and especially to challenge marginalizing ideas related to both gender and race identity, to bring racialization to other places, to make it function with other bodies/objects. In this drawing activity, some mirrors are set up at a table with drawing paper and black pencil crayons. The children, who are of various racial backgrounds, begin to discuss the "beauty marks," "freckles," and "pink lines" they see on their faces. The child who drew herself as Rapunzel now draws herself smiling, with her hair in a "pom-pom" (ponytail). The mirrors activate new forces in the children's investigation of identities, magnifying new becomings. The mirrors, the reflections, the crayons with their intense smell, the proximity of the children's bodies around the table,
\end{abstract}


the children's different phenotypes, the light that comes into the room, what children say at that moment, and other human and non-human things form a machinic assemblage. The children become interested in the materiality of their bodies, what bodies are capable of doing and becoming. Perhaps a stuttering in the concept of identities and self-views is happening here. Racialization takes a different form. Where does it take us? How does it transform itself in front of our eyes, ears, mouths, stomachs, and so on? How does each of the myriad encounters transform us as a part of the assemblage? What kinds of new assemblages emerge? Our interest is in how these bundles of practices that come together but do not necessarily stay together enact the assemblage we call racialization.

This paper considers how research practices on racialization in early childhood education might be reconceptualized when racialization is placed within relational intricacies and affects in multiple encounters. By foregrounding race and its emergence in multifarious, unpredictable ways in everyday encounters between human and non-human bodies, space, and discourse, the paper investigates how a movement toward research analyses that engage with both the materiality of race and its systemic and discursive formations might be used to constantly seek new ethical ways of responding to and acting against racisms and colonialism in early childhood. First, we will elaborate on the idea of 'race' as an event within the context of early childhood education. We reiterate and elaborate on some of our previous work on racialization in early childhood education in which we outlined the sociomaterial networks of racialization and reconsidered race as a doing (Pacini-Ketchabaw \& Berikoff, 2008; Pacini-Ketchabaw \& Nxumalo, 2010). We review the work of several scholars who are examining how bodies do race at both a material/physical level and in relationship with discursive constructions of race (Nayak, 2010; Saldanha, 2006; Slocum, 2008; Veninga, 2009). Next, we address methodological challenges that invite us to think differently about data analysis. We are interested in how we as researchers specifically exploring issues regarding the study of racialization as a sociomaterial phenomenon in early childhood could rethink our data analysis practices. We discuss how we might move from a social constructionist, critical analysis approach to the study of racialization toward an approach that allows us to research race as a practice with all its multiplicities and how we can make our data proliferate towards anti-racist and anti-colonial spaces. To shape our arguments, we borrow from the work of scholars challenging normalized understandings of qualitative research (MacLure, 2010a, 2010b; Law, 2004; Mol, 2002; Stewart, 2008). Finally, we return to the excerpt that opened our paper and explorations with data analysis, and we offer two additional examples. In both examples we attempt to go beyond the obvious, the desire to explain and represent what research subjects say and do, with the goal of interrupting the usual workings of qualitative research (MacLure, 2011).

\section{Sociomaterial Perspectives on Racialization}

Early childhood education has responded to the systemic (rather than individual) realities of social injustices by analyzing the ways in which language and discourse work to create conditions of inequality. Drawing from postfoundational theories such as poststructuralism, postcolonialism, and anti-racist feminism, amongst others, reconceptualist early childhood scholars have provided great insight into the role of systemic inequities and dominant discourses in creating social injustices in young children's lives (Mac Naughton, 2001, 2005; Mac Naughton \& Davis, 2009; Pacini-Ketchabaw, White \& Armstrong de Almeida, 2006; Robinson \& Jones-Diaz, 2005; Ryan \& Grieshaber, 2005; Viruru, 2005). Attention to the ways in which racial identities are produced within different and competing discourses has opened up many 
possibilities for social just pedagogies grounded in socio-political contexts. This work has provided very useful theoretical and pedagogical resources for thinking about and acting towards practices that make visible relations of power, structural injustices and intersecting inequities (Bhabha, 1994; Collins, 2000; hooks, 1989; Lee \& Lutz, 2005; Mohanty, 2003; Stoler, 2008). For example, post-colonial, anti-racist feminist perspectives enable a consideration of the factors that put marginalized groups at risk " particularly from discursive and material violence exercised by the dominant society"(Jiwani, 2006, p. 19). From a systemic and discursive perspective, we can see how children's racialized identities and understandings of racialization are mediated by dominant discourses in their particular social contexts. While children exert agency in what they see as desirable (for example, what they choose to draw), this agency is mediated and constrained by the available discourses constructing race (Mac Naughton, 2005). Attention to the ways in which racial identities are constantly being produced anew within different and competing discourses (Lather, 1991) is an important part of creating socially just possibilities. This has been critical in creating movement beyond early childhood pedagogical responses based on pre-specified universal developmental conceptions of children and beyond responses framed by generalized multicultural representation and fixed identity recognition (Pacini-Ketchabaw, 2007; Pacini-Ketchabaw \& Berikoff, 2008; Vandenbroeck, 2007). For example, by considering the discourses at work in the classroom, educators and researchers can critically reflect on why racialized children may see whiteness as desirable and powerful as they negotiate their belonging within a particular social context. Educators and researchers can also begin to deconstruct whiteness and contest subject positions that privilege whiteness as desirable and powerful within a specific context (Mundine \& Giugni, 2006; Mac Naughton \& Davis, 2009).

Recently, early childhood scholars have also made us aware of the need to reintroduce perspectives that focus on materiality by referring to sociomaterial relations (see Olsson, 2009; Lenz Taguchi, 2009). Materialist ontologies of race focus on how bodies do race through emergent material/discursive relations, drawing inspiration from Deleuzean theories on becoming and feminist corporeal theories that foreground both the body and the material world in the mediation of experiences (Barad, 2007; Deleuze \& Guattari, 1987; Grosz, 1994, 2005; Haraway, 1988). In a material-discursive conception, race is understood as interactions of different material, affective and discursive elements that can come together in any encounter (Amin, 2010; Nayak, 2010; Saldanha, 2006; Slocum, 2008; Swanton, 2010; Veninga, 2009). Following Deleuze and Guattari, Saldanha (2006) conceptualizes race as a machinic assemblage-an event. To bring the complex materiality of the social to discussions of racism without falling into the essentializing nature of most biological theories of race, Saldanha (2006) argues, we need to move beyond the idea of race as a taxonomic ordering, "a logic of solids and grids" (p. 19). Instead, race needs to be "conceived as a chain of contingency, in which the connections between its constituent components are not given, but are made viscous through local attractions" (p. 18). He argues that a nonessentialist understanding of race challenges the binary of self/other and sees bodies as emergent. He proposes to engage in theorizing "the heterogeneous [and complex] materiality of the social" that involves rethinking biology as fixed and given to think of it instead as "the science of life: of movement and unpredictability at every level" (p. 16). This rethinking moves away from the idea that racial hierarchy is "natural" and therefore unavoidable: "Human phenotypes can be understood as continuous and multifaceted, not discrete or linear; as much products of isolation as of migration and miscegenation" (p. 17). 
What becomes important in practice/research is to understand how race works, "how economic, cultural, phenotypical and other disparities open those bodies to certain kinds of interactions and transformations" (Saldanha, 2006, p. 25). Materialist ontologies of race also highlight the capriciousness, mobility, and inventiveness of race, as well as the tendency for repetitions of racialization in relational encounters made in connections between material (such as phenotype, buildings, clothing, aromas, music, suspicion) and systemic/discursive effects (such as urban segregated ghettos, religion, the remnants and rearrangements of colonialism, multiculturalism, law, language, and migration (Swanton, 2008; Saldanha, 2010a). For example, an ethnographic study of a racially and ethnically diverse town in the United Kingdom described the ways racialization emerges through everyday encounters with brown bodies, prayer caps, veils, beards, turbans, corner stores, rucksacks - through the visceral connections and affects in this assemblage, brown bodies come to be seen as "radical" Muslims and terrorists (Swanton, 2008). Another example would be in the assemblages made in racializing encounters with brown bodies, loud music, flashy cars, fear, memories of news headlines and music videos -in this assemblage, brown bodies become drug dealers (Amin, 2010; Swanton, 2008). Encounters such as these are repeated and aggregated to create race as a force in everyday life. Thinking through race as a fluid and emergent ontological encounter suggests that what happens as a result of encountering difference can change as settings and contexts shift and perceptions change (Swanton, 2008, 2010). As seen in the previous examples, each encounter may sediment and increase inequitable relations and separate people (leading to the sedimentation, reinforcement, or creation of racisms such as avoidance, indifference, suspicion, and judgment of the other). However, each encounter also holds potential for "ethical engagement with otherness" (Saldanha, 2006, p. 14) and for new, unexpected effects and lines of flight. In this way, race proliferates in rhizomatic, "constantly morphing" ways (Swanton 2008; Saldanha, 2006, p. 20).

An important aspect to note is that engaging with phenotype does not suggest an essentialist view of race, but recognizes phenotype as unstable in its corporeal connections with other "things," including places, objects, and other bodies. Skin plays an active role in creating both divisions and ethical interactions in encounters with racial difference (Slocum, 2008). In this view skin is:

a site of subjectivity, crisis, desire [and] instability that has productive potential, and thus an active role in the emergence of race and racialization; such as whether bodies stare at each other ... are glimpsed or ignored ... are moved or forced to stop ... meander ... stride ... give way and stand [their] ground, prevent [or] enable (Slocum, 2008, p. 854).

Following the tradition of feminist antiracist and postcolonial scholars, sociomaterialist ontologies of race also create a disruption in the notion of an autonomous subject. Drawing from feminist corporeal theories, subjectification, including racialized subject formation, is understood not only as the processes by which we position ourselves (in normalizing and subversive ways) and are positioned within dominant discourses but also in terms of the material processes that come into being in conjunction with, or preceding linguistic and symbolic representation in the formation of subjectivities (Grosz, 2005; Lenz Taguchi, 2009; Rossholt, 2009). Subjectivity is conceptualized as never complete, nomadic, non-linear processes of multiple, dynamic, and often unpredictable experiential resonances and becomings. The subject is conceptualized as in continuous relational intra-action with the world; "a folding-in of external influences and a simultaneous unfolding-outwards of affects" (Braidotti, 2008, p. 32). 
Bodies become through what they do, the relations of which they are a part and the formations in which they act. Corporeality, then, refers to a dynamic capacity of human bodies to emerge in relation to each other and to things, within social and physical limits, and thereby to form sexual and racial [becomings] (Slocum, 2008, p. 853).

In this conceptualization of subjectivity, the corporeality of the body, including the racialized body, is central, but not as an inert or reified target of discourses (Saldanha, 2010b). Bodies and their actions, perceptions, and affects interact with things, spaces, and discursive elements in the emergence of subjectivity as an embodied and embedded assemblage of multiple belongings-made, remade, and potentially transformed in heterogeneous relational connections to create and recreate a subject-in-process (Alexander \& Knowles, 2005; Braidotti, 1998; Deleuze \& Guattari, 1987; Gallacher \& Gallagher, 2008).

To summarize, a sociomaterial theorization of race unpacks processes of racialization by attending to discursive effects following feminist antiracist and postcolonial writings, as well as the materiality of what actually happens to bodies, what they do, and their phenotypical distribution in certain spaces (Saldanha, 2006; Slocum, 2008; Swanton, 2010; Veninga, 2009). A sociomaterialist approach to race considers how different physical forces come together (such as other material objects, surroundings, and phenotype) with discursive, systemic forces to make race matter in each encounter with difference (Saldanha, 2006). Physical differences between bodies can assemble in unpredictable ways with myriad perceptions (such as "raced" memories and feelings), practices, material affects, and other contingencies to mediate everyday encounters (Grosz, 1994; Slocum, 2011). A sociomaterialist approach to race also suggests that we need to engage in understanding what race (or gender or sexuality) "is and can $b e$, in as many variations as possible" (Hames-Garcia, 2008, p. 330). Understanding what race can be allows us to work toward making race work differently. What new elements can race be linked to and, as a result, transformed into something new? What kinds of encounters are possible?

\section{Engaging Methodologically with Racialization}

In the previous section, we explored theoretical perspectives on racialization, presenting a sociomaterial perspective. In this section, we address methodological issues that we then employ to come back to our research on racialization in early childhood education. How might these methodological considerations allow us to rethink and open up our own research practices on racialization? We review several scholars' writing on the revisioning of qualitative inquiry, specifically we are interested in non-representation in research practices. ${ }^{1}$ In our qualitative research on racialization in early childhood education, we have examined the social construction of whiteness, considered the critique of multiculturalism, and done extensive work with young children by exposing the racial power games and the reconfiguration of these games in early childhood classrooms (Pacini-Ketchabaw, 2007; Pacini-Ketchabaw \& Nxumalo, 2010; Pacini-Ketchabaw, White \& Armstrong de Almeida, 2006). We have also explored the race

\footnotetext{
${ }^{1}$ We situate our work within the important and innovative works that have been published on rethinking qualitative research (e.g., Clark/Keefe, 2010; Jackson \& Mazzei, 2009; Lather, 2007; Martin, 2008; Ramazanoglu \& Holland, 2007; Rhedding-Jones, 2005; St. Pierre, 2011; Wilson, 2008). However, we specifically concentrate on work that we find productive to expand a sociomaterial approach to racialization research that challenges representation in research practices.
} 
hierarchies and the dynamics of race relations that are commonplace in early childhood classrooms. We have become very skilled in reading transcripts (of conversations among children and educators) from multiple perspectives (e.g., a multicultural perspective, a developmental perspective, an anti-racist perspective).

However, as we reflect back and consider sociomaterial perspectives on racialization, we find that our approaches to researching racialization in early childhood might benefit by expanding our practices of research analysis. MacLure (2010) explains that, in fact, research that uses postfoundational and critical theories, as ours has done, inevitably fails to be "ruinous" - that is, to bring change. The problem, she says, is that theory has not had enough of a chance, then, to proliferate through sustained entanglement and interference with its objects-with their details, their intransigent singularity and their perplexing otherness. It has not folded, deviated and differed from itself in trying to get to grips with 'data' whose complexity always exceeds its reach. It has not grappled with the vertigo of sometimes seeming to float above the 'feckless particular'... and at other times being dragged and dispersed among its mundane detail. It has not pierced or eroded the solid walls of common sense or received practice (MacLure, 2010. p. 4).

If race itself is not a thing, but an event, researching race entails not only asking people about their experiences or just understanding how racialization is mediated in various social fields. Law (2004) argues that "simple clear descriptions don't work if what they are describing is not itself very coherent" (p. 2). Instead, he suggests that we begin to trace and map practices and events as well as their interrelations. We need methods, he says, that go beyond collecting and manipulating qualitative or quantitative materials (e.g., how children respond to our questions on racialization). He further argues that our task is "to imagine methods when they no longer seek the definite, the repeatable, the more or less stable. When they no longer assume that this is what they are after" (p. 6). If race is understood as fluid, contingent, mutable (as Saldanha and others have noted), we need methods that do more than just map or chart what race is. We need methods that account for a world thought as "filled with currents, eddies, flows, vortices, unpredictable changes, storms, and with moments of lull and calm" (Law, 2004, p.7) because this is also what race is filled with. MacLure (2010) suggests that we need "more materially engaged research practices" that pay attention to "more sustained engagements with the opaque complexity of lives and things" (p.4). She argues for a research praxis that attends to sensations, forces and movements beneath the skin, in matter, in cells and in the gut, as well as between individuals and groups. This kind of empiricism traces intensities of affect that move and connect bodies, subatomically, biologically, physically and culturally. It doesn't privilege human interpretation or conscious perception, and the bodies that are animated by affect are by no means restricted to human bodies (p. 5).

In a similar vein, Kathleen Stewart (2008) invites an ethnography that attends to "the textures and rhythms of forms of living as they are being composed and suffered in social and cultural poesis" (p. 71). This is a process that attends to things in the middle:

Things that have impact. Things caught in a circuit of action and reaction. Not simple or self-contained things, but things like the way the senses literally jump in moments of spacing out or ducking for cover, or the sad sagging of 
trajectories that held promise just a minute ago, or the serial build-up of the sense of being in one thing and then another (Stewart, 2008, p. 71).

This is a methodology that, rather than following a particular theoretical path, becomes "unstuck from its own line of thought to follow the objects it encounters, or becomes undone by its attention to things that don't just add up but take on a life of their own as problems for thought" (Stewart, 2008, p. 72). A methodology that becomes unstuck from itself does not necessarily describe or pin down where things came from and what they are, but instead describes "the moment itself when an assemblage of discontinuous yet mapped elements throws itself together into something" (p. 73). In this "weak methodology" the goal is not to provide a representation of something, "but to wonder where [analytic objects] might go and what potential modes of knowing, relating, and attending to things are already somehow present in them as a potential or resonance" (p. 74). Another interesting methodological challenge with much potential is one presented by Annemarie Mol. In her study of atherosclerosis, Mol proposes to approach research through praxiography-a relational, sociomaterial, and processual research strategy. She views disease as a series of practices instead of a thing, and engages with these practices as sites where subjects and objects acquire their shape and definition. By exploring the different practices that enact the disease, Mol argues that atherosclerosis is multiple. We see the potential of praxiography as a research strategy for studying how race-and other social relations of power such as gender, class, and nation (among others)-is done, practiced, or enacted in early childhood. The use of praxiography would allow us to ask questions about the praxis of race, rather than providing answers that mobilize its meanings.

What many of the above mentioned methodological movements have in common is that they confront representation. Law (2004) argues that through representation, research has rendered invisible the "authorship, the uncertainties, the enactment of out-thereness" (p. 88). He says:

There is nothing direct or literal about the link between present statements and the absent realities. This means that those statements come out (or are telling) of something other more than the reality they describe. They are effects of allegory that conceal their allegorical origins. That is what representation is: allegory that denies its character as allegory (p. 89).

In Law's (2004) view, confronting representation in research practices brings methods to the realms of localities, specificities, enactments, multiplicities, fractionalities, resonances, gatherings, dances, imaginaries, passions, interferences. MacLure, Holmes, MacRae and Jones (2010, p.544), drawing on Deleuze's philosophy, speak of interferences and "ways of interrupting ourselves" from reproducing the normal in our own research practices. Using data from her ethnographic research, they produced a film that acts to "jam or break" vision in order "to evade some of the closures of propositional language, argument, narrative and interpretation, through an assemblage that deploys montage, cutting, oscillations of space and scale, disconnections of sound, vision and script and the jolt of the irrational cut (p.544). Their purpose is to "mobilise the barely formed, dimly glimpsed sensations that comprise 'affect" (p.544). We find this movement in qualitative research productive in introducing "some small glitch in the machinery that produces" racisms and social injustices (p.544). We see potential in interrupting social injustices through research practices that make visible the situated particularities and disparate connections through which race emerges; methodologies that confront racialization and neocolonialisms on their slippery territory. We see possibilities for 
creating disruptions by attending to the intensities of certain encounters, to everyday sites and situations that link to racialization and colonization. We see these methodological strategies as providing an opening to resituate "the subject out of identity politics into a non-unitary or nomadic vision of selves" (Braidotti, 2006, p. 266).

To summarize, our wanderings and wonderings into various methodological assemblages lead us to propose that the mobility and multiplicity of race call for a nomadic, mobile, and experimental approach to research practices on racialization. We propose research practices that are always becoming, that open up connections between different ideas to continually seek new ethical ways of thinking and acting, that collapse binaries and, importantly, seek creative ways to expand engagements with race. We borrow the term 'nomadic' from Deleuze and Guattari (1987) to refer to the creation of spaces and ways of thinking that open new directions and routes in research practices and resist codified or normalized ways of thinking and acting. In a nomadic research act, researchers would not necessarily follow already existing guidelines that define what counts as good research practice, but we would act toward the creation of new ways to confront dominant research practices and move toward seeking new potentials (Colebrook, 2002), asking, for example: Where else could this go? What kinds of new encounters are possible? What new "things" can race be linked to and, as a result, transformed and rearranged into something new?

\section{Stuttering Racisms and Colonialism in Early Childhood Research}

We opened our paper with an excerpt of our data analysis of an ordinary moment in a classroom, one which we have written about in greater detail elsewhere (Pacini-Ketchabaw \& Nxumalo, 2010). Our purpose in presenting the excerpt of our analysis of children exploring their identities with mirrors and crayons is to pay close attention to the enactment of racialization in early childhood as well as attend to 'things in the middle'. In the excerpt, race becomes an event constituting "an assemblage of things, phenotypes and practices which is made, remade, revised and reformed in the constant flux (and occasional showcase event) comprising daily life" (Smith, 2009, p. 500). We try not to make claims about what race is but explore instead how race emerges as an assemblage in the very practices of early childhood education. We don't attend to racialization in general, but to situated enactments and partial connections (Strathern, 2004).

Below we provide two additional examples from our data from two different action research projects with early childhood educators (Pacini-Ketchabaw \& Berikoff, 2008; Rowan, 2011). Here, unlike our introductory example, we focus on making racisms stutter. We are interesting in showing how we can make the data 'do' things. Following MacLure and colleagues (2010), we attempt to create interruptions in our data using art as a vehicle for that disruption. We are not looking for answers nor do we claim that there are direct links between our data and the art we highlight. Instead, we use these spaces to interrupt racisms. Perhaps we can say that there is some irrationality as the various elements we use come together. We do not present these examples as the only ways in which to interrupt racisms and colonialism, but rather as examples of how we are trying to approach data analysis in our work. In fact, readers will experience the disruptions in a multitude of ways. As MacLure and colleagues (2010) warn us in relation to their film:

Future viewers, or we ourselves on another occasion, may find that the film fails to fracture the old colonial relation of the knowing researcher and the pliant data. Or that its dispersed structure smuggles in argument and critique under cover of an illusory 
openness. Or that its momentary disconcertions are too easily reabsorbed into the narrative comfort of the 'already known'. Hoping to engage affect, we may simply have rechannelled the potency of cheap sentiment (p. 554).

We are, of course, taking similar risks here.

The second example, titled Stand Up, emerges from a dialogue between three young children and an early childhood educator in a child care centre (Pacini-Ketchabaw \& Berikoff, 2008). In this project we were investigating the workings of racialization in everyday early childhood education.

Winston: My grandmother says that Black people are stupid and Native people are more stupid.

Tyronne: You need to shut the fuck up.

Winston: Kaya! Jahrul and Tyronne want to beat me up.

Kaya: Why?

Jahrul: Because him says we're stupid and more stupid.

Kaya: Can you talk about it?

Jahrul: Yeah, but we like to beat him up.

[Jahrul and Tyronne give each other high fives.]

Kaya: I think you should use your words.

Tyronne: What words? Funny, really funny.

Kaya: Thoughtful words.

Jahrul: OK, tell your grandmother we beat her up, too.

Kaya: Jahrul, your mother wouldn't like that. She wants you to grow up to be a gentleman.

Jahrul: Kaya wants me to be a strong man, a true man, a great man.

Tyronne: A rich man.

Winston: I just said my grandmother says you're stupid. I don't believe that, and my mother says it's wrong and unkind.

Kaya: What did your grandmother say?

Winston: That Black people were stupid and that Native people were stupid.

Kaya: Tell your grandmother that Kaya needs to speak with her.

[Jahrul and Tyrone are overjoyed.]

Tyronne: Tell your grandmother that Kaya beat her up (pp. 257-258.).

Elsewhere we explained how this dialogue provoked much discomfort among the educators and researchers involved in the project. We were initially disturbed at the language the children were using and the harassment we read from our own positions. Rather than attempting to explain what might be at work in this dialogue (representation), here we consider MacLure's (2010) proposition to "obliterate easy signification attempting instead to release a more open array of responses that are less burdened with the weight of prior assumptions" (p. 283). MacLure's suggestion puts us in mind of the work of Brian Jungen, a Vancouver artist who, instead of presenting objects "as they are," reworks them without fully concealing their original meaning or purpose. For example, Jungen has turned white plastic chairs into the skeleton of a whale and suspended it in the air. He has taken apart Nike Air shoes and restitched them into First Nations masks, and fashioned totem poles from high-end golf bags (Canadian Broadcasting Corporation, 2009). 

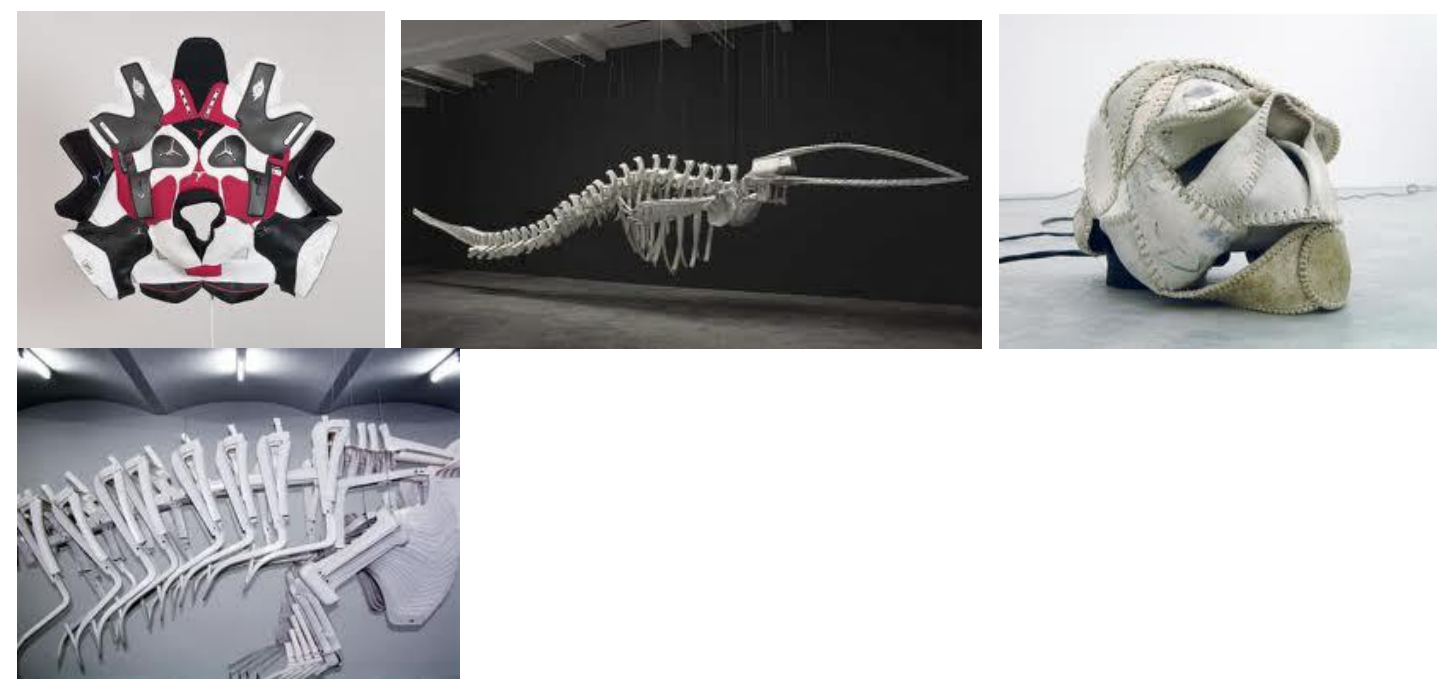

CBrian Jungen

Jungen disassembles and then reassembles objects in new ways, so that the viewer of his art can recognize the source object while opening to new meanings, often indefinable ones. By attending to Jungen's work, we are interested in how he makes racism and colonialism function as an assemblage-an assemblage that does not explain colonialism and racism but rather disturbs it. It makes colonialism and racism stutter by linking them to unfamiliar but deeply related elements that work through neocolonial appropriation. Jungen's work invites unexpected responses to racism and colonialism. In a similar way, we invite the reader to respond to the dialogue Stand Up (an assemblage in which race functions in specific ways and is made to function by all the bodies that come together in particular ways) alongside Jungen's work. What do these two assemblages do together? How do they function? What possibilities do they provoke? The analysis we are proposing here would work more at the level of affects than at the linguistic level. How does racism and colonialism get interrupted as these two assemblages (Stand Up and Jungen's work) come together to form a new assemblage?

In our third example, we also focus on making colonialism and racism in early childhood education stutter. Here our context is an action research project on Indigenous early childhood practices (Rowan, 2011). Again, rather than provide the reader with our responses, we offer this example as a problem for experimentation. The data below include an entry from one of the author's research journal reflections, and a brief moment from observations in a child care centre in Nunavik (Northern Quebec) describing children and educators in the process of feeding.

I remember a moment at camp on the shores of Hudson's Bay in Arctic Quebec. The hunters had returned with a seal and our group gathered around the seal, sitting in a circle on the hard rock, to eat the food. I sat beside a young Mom, she held an ulu in her hand and cut a small piece of the fresh raw red meat. She placed the meat in her own mouth and chewed, then turning to her baby, removed the chewed food from her mouth and lovingly whispering "ababa" to her child, placed the pre-chewed food in her babies mouth (research journal entry).

Six babies are sitting with two educators at a feeding table. The table is a half circle - flat on one side with a indented space cut-out where the two educators sit, on adult sized 
plastic chairs. The 6 yellow plastic baby seats have been inserted and distributed evenly into spaces on the round side of the table. Each seat is occupied. Upon the surface of the table, in close proximity to the two educators, sit six yellow melamine plates ladened with bite-sized pieces of French toast. There is a spoon for each child, which the educators use while giving a bite of food to one child, before moving onto the next. One little boy stretches to reach a plate of food, but it rests beyond his grasp (field observations).

These are two powerful moments in our research data that speak to us of racialization and colonialism. But rather than explaining what might be happening here, we attempt to make the data 'proliferate'. To proliferate our ideas and to open the possibility of entering into new spaces, we place these two data excerpts alongside a film titled InukShop ${ }^{2}$. In this film, director Jobie Weetaluktuk played with cultural appropriation and followed the movement of the stone man Inukshuk from the Arctic land, to a plastic container in a tourist shop and finally situated in an urban setting on the grounds of a museum. This video was created for the 2010 Vancouver Olympics. The film opens with grass blowing in the wind, we see a stone, and then an Inukshuk (a man made of stones) standing on the land. Then, we see a living man, performing on a drum, wearing sixties style clothing. He has a large audience of approximately 20 Inuit, standing on the land, watching. A carving of a drummer flashes across the screen, and then details are honed: the drum, the man, a statue in the museum. A hand carved whale is polished. We see vintage film footage featuring a hunter in a kayak as he harpoons a whale, on the sea. Then a stone image - a carving of a man in a kayak, followed quickly by more old footage of a narwhal brought to shore, the hunter standing, carefully examines the tusk, the eyes and checks the skin. A carved stone whale is presented and then a picture of an igloo being made by a man, standing on the snow; which merges to the image of a stone igloo, which leads to the plastic snow globe igloo which can be hand shaken to make the snow appear. The stone carvings become Inukshuk hockey players and then a snow boarder. An image of a line-up of plastic Inukshuks with Canada emblazoned across the base screens, a price tag $\$ 5.99$ appears and then a tray filled with plastic Indian dolls. The screening ends with the picture a stone Inukshuk in the garden of the museum, standing in the shadow of a looming skyscraper.

By placing these three pieces side by side, and sharing them with the reader in this paper, we are curious to what they do together. Many questions emerge for us. We attempt to create some productive spaces for making our data stutter against racisms. We wonder about how colonialisms and racisms act through the appropriation of bodies in our data of feeding practices in the early childhood classroom? What emerges in this assemblage? What emerges in the assemblage educator-child-spoon-food-table-and-more? How does the spoon come to matter in the very act of colonialism? How do the plates matter? How does the table matter? How are the tables, plastic chairs, metal spoons, and their configurations in the room all active participants in food-eating practices as colonial acts? How might we reconsider the workings of neocolonialisms and racialization through everyday food-eating practices (Slocum, 2011)? How are the sociomaterial aspects of race mobilized in these encounters connected to systemic racisms and colonialisms (Jiwani, 2006; Subedi \& Daza, 2008, Swadener \& Mutua, 2008)? How do these fragments perpetuate or disrupt forces of racism and colonialism?

\footnotetext{
${ }^{2}$ To view the film, please go to http://www.nfb.ca/film/vistas_inukshop_en
} 


\section{Conclusion}

In this paper, we have elaborated on the idea of racialization as an event within the context of early childhood education. We have discussed how we as researchers who explore issues around racialization in early childhood come to work methodologically with the idea of race as an event. We have considered how we might move from a social constructionist, critical analysis approach to studying racialization toward an approach that allows us to both research race as a practice, with all its multiplicities, ambiguities, and uncertainties as well as analyze our research data in ways that we can make racisms and colonial enterprises stutter (rather than representing them). By sharing three examples from our research, we have asked the reader to join with us, not to apply the theories we've presented to our examples, but to proliferate theories, as MacLure (2010a, 2010b) suggests. Just as Brian Jungen and Jobie Weetaluktuk are doing with their art, our goal is to experiment, evoke, disturb, provoke. In these processes, we hope, lies change.

\section{References}

Alexander, C. \& Knowles, C. (2005). Introduction. In: C. Alexander \& C. Knowles (Eds.), Making race matter: Bodies, space and identity, pp. 1-16. New York: Palgrave Macmillan.

Amin, A. (2010). The remainders of race. Theory, Culture \& Society, 27(1), 1-23.

Barad, K. (2007). Meeting the universe halfway: Quantum physics and the entanglement of matter and meaning. Durham, NC: Duke University Press.

Bhabha, H.K. (1994). The location of culture. London: Routledge.

Braidotti, R. (1998). Difference, diversity and nomadic subjectivity. Retrieved from http://www.ministeriodejusticia.cl/pmg/documentos/Differencem\%20diversit y\%20 and\%20nomadic\%20subjectivity.pdf

Braidotti, R. (2006). Transpositions: On Nomadic Ethics. Cambridge: Polity Press.

Braidotti, R. (2008). Of poststructuralist ethics and nomadic subjects. In M. Düwell, C. Rehmann-Sutter, \& D. Mieth (Eds.), The contingent nature of life (pp. 25-36). Netherlands: Springer.

Canadian Broadcasting Corporation (CBC). (2009). Brian Jungen. Retrieved from: http://www.cbc.ca/asithappens/features/2009/10/21/brian-jungen/

Clark/Keefe, K. (2010). Invoking Mnemosyne: Art, memory, and the uncertain emergence of a feminist embodied methodology. Rotterdam: Sense Publishers.

Colebrook, C. (2002). Gilles Deleuze. New York, NY: Routledge.

Collins, P. H. (2000). Black feminist thought: Knowledge, consciousness, and the politics of empowerment (2nd ed.). New York: Routledge.

Deleuze, G., \& Guattari, F.L. (1987). A thousand plateaus: Capitalism and schizophrenia. Minneapolis: University of Minnesota Press.

Gallacher, L. A., \& Gallagher, M. (2008). Methodological immaturity in childhood research? Childhood, 15(4), 499-516.

Grosz, E. (1994). Volatile bodies: Toward a corporeal feminism. Bloomington: Indiana University Press.

Grosz, E. (2005). Time travels. Feminism, nature, power. Durham: Duke University Press. Hames-Garcia, M. (2008). How real is race? In S Alaimo \& S. Hekman (Eds.), Material feminisms (pp. 308-339). Bloomington: Indiana University Press.

Haraway, D. (1988). Situated knowledges: The science question in feminism and the privilege of partial perspective. Feminist Studies, 14(3), 575-599. 
hooks, b. (1989). Talking back: Thinking feminist, thinking black. Boston: South End Press.

Jiwani, Y. (2006). Discourses of denial: Mediations of race, gender, and violence. Vancouver: UBC.

Jackson, A., \& Mazzei, L. (Eds.). (2009). Voice in qualitative inquiry: Challenging conventional, interpretive, and critical conceptions in qualitative research. New York: Routledge.

Lather, P. (1991). Getting smart: Feminist research and pedagogy with/in the postmodern. New York: Routledge.

Lather, P. (2007). Getting lost: Feminist efforts toward a double(d) science. Albany, New York: State University of New York Press.

Law, J. (2004). After method: Mess in social science research. London: Routledge.

Lee, J.A. \& Lutz, J.S. (2005). Introduction: toward a critical literacy of racisms, antiracisms, and racialization. In J.A. Lee \& J.S. Lutz (Eds). Situating 'race' and racisms in space, time, and theory. Montreal: McGill-Queen's University Press.

Lee, R. L. M. (2010). On the margins of belonging. Journal of Sociology, 46(2), 169-186.

Lenz Taguchi, H. (2009). Going beyond the theory/practice divide in early childhood education: Introducing an intra-active pedagogy. New York: Routledge.

MacLure, M. (2010a). Qualitative inquiry: where are the ruins? Keynote presentation to the New Zealand Association for Research in Education Conference, University of Auckland, December 2010.

MacLure, M. (2010b). The offence of theory. Journal of Education Policy, 25(2), 277-286.

MacLure, M., Holmes, R., MacRae, C., \& Jones, L. (2010). Animating classroom ethnography: Overcoming video-fear. International Journal of Qualitative Studies in Education, 23(5), 543-556.

Mac Naughton, G. (2001). Beyond 'othering': Rethinking approaches to teaching young Anglo-Australian children about Indigenous Australians. Contemporary Issues in Early Childhood, 2(1), 83-93.

Mac Naughton, G. (2005). Doing Foucault in early childhood studies: Applying poststructural ideas. New York: Routledge Falmer.

Mac Naughton, G., \& Davis, K. (2009). "Race" and early childhood education an international approach to identity, politics, and pedagogies. New York, NY: Palgrave Macmillan.

Martin, K. L. (2008). Please knock before you enter: Aboriginal regulation of Outsiders and the implications for researchers. Teneriffe, Qld: Post Pressed.

Mohanty, C. (2003). Feminism without borders: Decolonizing theory, practicing solidarity. Durham: Duke University Press.

Mol, A. (2002). The body multiple: Ontology in medical practice. Durham, NC: Duke University Press.

Mundine, K., \& Giugni, M. (2006). Diversity and difference: Lighting the spirit of identity. Research in Practice Series, 13(3), 1-21.

Nayak, A. (2010). Race, affect, and emotion: young people, racism, and graffiti in the postcolonial English suburbs. Environment and Planning A. Retrieved from http://www.envplan.com/epa/fulltext/aforth/a42177.pdf

Olsson, L. M. (2009). Movement and experimentation in young children's learning: Deleuze and Guattari in early childhood education. New York: Routledge. 
Pacini-Ketchabaw, V. (2007). Child care and multiculturalism: A site of governance marked by flexibility and openness. Contemporary Issues in Early Childhood, $8(3), 222-232$.

Pacini-Ketchabaw, V. (2010). Introduction: Resituating Canadian early childhood education. Alberta Journal of Educational Research, 56(3), 241-245. Retrieved from http://ajer.synergiesprairies.ca/ajer/index.php/ajer/article/view/820

Pacini-Ketchabaw, V., \& Berikoff, A. (2008). The politics of difference and diversity: From young children's violence to creative power expressions. Contemporary Issues in Early Childhood, 9(3), 256-264.

Pacini-Ketchabaw, V., \& Nxumalo, F. (2010). A curriculum for social change: experimenting with politics of action or imperceptibility. In V. PaciniKetchabaw (Ed.), Flows, rhythms \& intensities of early childhood education curriculum (pp. 133-154). New York, NY: Peter Lang.

Pacini-Ketchabaw, V., White, J., \& Armstrong de Almeida, A. E. (2006). Racialization in early childhood: a critical analysis of discourses in policies. International Journal of Educational Policy, Research, and Practice, 7(1), 95-113.

Ramazanoglu, C., \& Holland, J. (2002). Feminist methodology: Challenges and choices. Los Angeles, CA: Sage.

Rhedding-Jones, J. (2005). What is research? Methodological practices and new approaches. Oslo: Universitesforlaget.

Robinson, K. \& Jones Diaz, C. (2005). Diversity and difference in early childhood education: Issues for theory and practice. Maidenhead: Open University Press.

Rossholt, N. (2009). The complexity of bodily events through an ethnographer's gaze: Focusing on the youngest children in preschool. Contemporary Issues in Early Childhood, 10(1), 55-65.

Rowan, M.C. (2011). Exploring the possibilities of learning stories as a meaningful approach to assessment in Nunavik. Unpublished Masters thesis. University of Victoria, British Columbia, Canada.

Ryan, S. \& Grieshaber, S. (2005). Shifting from developmental to postmodern practices in early childhood teacher education. Journal of Teacher Education, 56(1), 3445.

Saldanha, A. (2006). Reontologising race: The machinic geography of phenotype. Environment and Planning D, 24(1), 9-24.

Saldanha, A. (2010a). Skin, affect, aggregation: Guattarian variations on Fanon. Environment and Planning A. Retrieved from: http://envplan.com/epa/fulltext/aforth/a41288.pdf

Saldanha, A. (2010b). Politics and difference. In B. Anderson \& P. Harrison (Eds.), Takingplace: Nonrepresentational theories and human geography (pp. 283-302). Aldershot, UK: Ashgate.

Slocum, R. (2008). Thinking race through corporeal feminist theory: Divisions and intimacies at the Minneapolis farmers' market. Social \& Cultural Geography, 9(8), 849-869.

Slocum, R. (2011). Race in the study of food. Progress in Human Geography, 35(3), 303327.

Smith, S. (2009). Author meets critics: a set of reviews and response. Introduction [Review of the book Psychedelic white: Goa trance and the viscosity of race, by A. Saldanha]. Social \& Cultural Geography, 10(4), 499-501. 
Stewart, K. (2008). Weak theory in an unfinished world. Journal of Folklore Research, 45(1), 71-82.

Stoler, A.L. (2008). Imperial debris: reflections on ruins and ruination. Cultural Anthropology, 23(2), 191-219.

St. Pierre, E. A. (2011). Refusing human being in humanist qualitative research. In N. Denzin \& M. Giardina (Eds.), Qualitative inquiry and global crises (pp. 40-55). Walnut Creek: Left Coast Press.

Strathern, M. (2004). Partial connections: Updated Edition. AltaMira Press.

Subedi, B., \& Daza, S. L. (2008). The possibilities of postcolonial praxis in education. Race, Ethnicity and Education, 11(1), 1-10.

Swadener, B., \& Mutua, K. (2008). Decolonizing performances: Deconstructing the global postcolonial. In N. K. Denzin, Y. S. Lincoln, \& L. T. Smith (Eds.), Handbook of critical indigenous methodologies. Singapore: Sage.

Swanton, D. (2008). Everyday multiculture and the emergence of race. In: C. Dwyer \& C. Bressey (Eds.), New geographies of race and racism (pp. 239-253). Aldershot, UK: Ashgate.

Swanton, D. (2010). Sorting bodies: Race, affect, and everyday multiculture in a mill town in northern England. Environment and Planning A, 42(10), 2332-2350.

Vandenbroeck, M. (2007). Beyond anti-bias education: Changing conceptions of diversity and equity in European early childhood education. European Early Childhood Education Research Journal, 15(1), 21-35.

Veninga, C. (2009). Fitting in: the embodied politics of race in Seattle's desegregated schools. Social \& Cultural Geography, 10(2), 107-129.

Viruru, R. (2005). The impact of postcolonial theory on early childhood education. Journal of Education, 35, 7-29.

Wilson, S. (2008). Research is ceremony: Indigenous research methods. Halifax: Fernwood. 